Asia Pacific Journals

\title{
COMBUSTION AND EMISSION CHARACTERISTICS OF MUNICIPAL SEWAGE SLUDGE IN OXYGEN-ENRICHED BUBBLING FLUIDIZED BED
}

\begin{tabular}{|c|c|}
\hline Rajesh Kumar* & Ravi Inder Singh \\
Department of Mechanical Engineering, Birla Institute of & Department of Mechanical Engineering, Birla Institute of \\
Technology \& Science, Pilani, Pilani Campus, Rajasthan, & Technology \& Science, Pilani, Pilani Campus, Rajasthan, \\
India. E-mail: rajesh.narota@ gmail.com, Tel: $(+91)$ & India \\
9465837776, *Corresponding Author. & E-mail: dr.rjassar@ gmail.com \\
\hline
\end{tabular}

\begin{abstract}
Municipal sewage sludge (MSS) disposal is one of the most complex environmental problem for India: as landfilling takes up a lots of land and contaminates, dumping into sea is harmful and some of MSS products are not suitable for the agriculture. Incineration is one of the promising method which utilized the heating value of the MSS to produce energy and reduced the sludge volume to small stabilized ash. Fluidized bed is used extensively for the MSS incineration worldwide. Oxygenenriched fluidized bed combustion is the one of latest method to control carbon dioxide. In the present work, the combustion and emission characteristic of municipal sewage sludge is carefully monitored and experimental measurements were obtained in a $20 \mathrm{~kW}$ bubbling fluidized bed (BFB) combustor under variable oxygen-enriched conditions. Temperature profile and emission in flue gas is studied at a suitable range of combustion temperature. The short fluidized bed combustor of $1.8 \mathrm{~m}$ in length is made from financial grant obtained from DST New Delhi India.
\end{abstract}

Keywords: Municipal sewage sludge (MSS), Fluidized bed, Oxygen-enriched, Combustion, Emission.

\section{INTRODUCTION}

India being a developing nation is currently facing many challenges and municipal sewage sludge (MSS) disposal is one of them. As the "Govt. of India" launching some scheme like "Clean India" to mitigate such a problem but the biggest question that laid in front of us is selection of the appropriate method for the disposal. The main disposal methods for the MSS are landfill, dumping in sea, recycling in agriculture, and incinerations. Incinerations is one of the significant method which give more advantage then the other methods. Werther et al. [1] discussed the three groups of thermal processing of sewage sludge like; mono combustion incineration, cocombustion and alternative process. The volume of the waste is reduced by the incineration. Neha et al. [2] presented the physical and chemical characteristics of municipal solid waste in Indian cities. It observed the possibility to produce clean energy from the incineration of MSS by using the advance combustion technologies like oxy-fired or oxygen-enriched fluidized bed combustor.

Fluidized bed technology is capable of burning different varieties of low carbon fuels with low emissions [3]. India, have been involved in the development of FBC systems since 1975. Han et al. [4] analyzed the combustion characteristics of sewage sludge in a fluidized bed combustor and concluded that MSS having moisture content less than $40 \%$ can stably burn without any auxiliary fuel input. Zhu et al. [5] proposed and investigated a new method of sewage sludge incineration which is divided into two stages and gives the higher combustion efficiency. Jang at al. [6] compared the combustion performance of the sewage sludge in air and oxyfuel circulating fluidized bed. It was observed that the range of $21 \%$ to $25 \%$ of oxy-combustion is more beneficial to apply carbon capture and storage technology (CCS) technology.

The objective of this work is to demonstrate the feasibility of bubbling fluidized bed combustor as a clean technology for burning the MSS under oxygen-enriched condition. The combustion and emission characteristic of MSS is carefully monitored and experimental measurements were obtained in a $20 \mathrm{~kW}$ oxygen-enriched bubbling fluidized bed (BFB). Temperature profile and emission in flue gas is studied at a suitable range of combustion temperature.

TABLE I. PROPERTIES OF MSS

\begin{tabular}{|c|c|}
\hline \multicolumn{2}{|c|}{ Properties of MSS } \\
\hline Proximate Analysis & Wt.\% \\
\hline Moisture & 24 \\
\hline Volatile Matter & 58 \\
\hline Ash & 4.1 \\
\hline Fixed carbon & $W t . \%$ \\
\hline Ultimate Analysis & 13 \\
\hline Carbon & 1.8 \\
\hline Hydrogen & 1.3 \\
\hline Nitrogen & -- \\
\hline Sulphur & 14 \\
\hline Oxygen & $3.5 \mathrm{MJ} / \mathrm{kg}$ \\
\hline GCV & \\
\hline
\end{tabular}

\section{METHODOLOGY}

\section{A. Fuel property}

The fuel used in this study is MSS which is collected from the sewage treatment plant Bits-pilani, pilani campus in dry form. The proximate and ultimate analyses of MSS are shown in the Table 1 . The MSS have the $3.5 \mathrm{MJ} / \mathrm{kg}$ gross calorific value. Sulphur concentration in MSS was not found.

\section{B. Experimental setup and procedure}

The work described in this paper is performed on a $1.8 \mathrm{~m}$ long square bubbling fluidized bed combustor is shown in Fig. 1. This combustor having two cyclones (C1 \& $\mathrm{C} 2)$, induced 


\section{Asia Pacific Journals}

fan, flue gas cooler and stack. The tests are performed on both enriched air-combustion mode and on oxygen-enriched combustion mode. The air and oxygen for the fluidization is entered through the distributor nozzle from the bottom side into the bed of the combustor and passes upward into the fluidized bed. The dry MSS for the combustion is entered through the hopper in dry form into the splash zone of the combustor. Temperature of bed, splash zone, and freeboard is measured at different height for each test when steady state is reached. The net thermal capacity of this system is below 20 $\mathrm{kW}$. The flue gas concentration is measured into the freeboard through port "S" by employing Testo-350 portable gas analyzer.

Fig. 1. Experimental Setup schematic

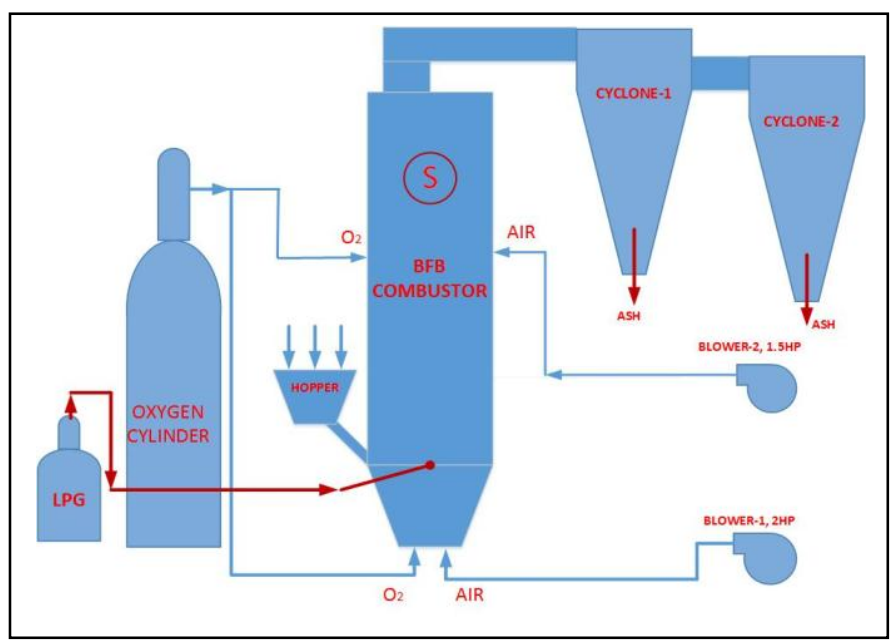

\section{RESULTS AND DISCUSSIONS}

A tests are performed on a bubbling fluidized bed when steady state is reached to investigate the effect of MSS (under both air-fired and oxygen-enriched condition) on the performance of a fluidized combustor and gas emission. The oxygen enhanced up to $20 \%$ and a constant fuel feed rate of approximately $18 \mathrm{~kg} / \mathrm{hr}$ was maintained throughout the experiments.

\section{A. Temperature profile}

Fig. 2 presents the temperature profile for the air-fired and oxygen-enriched condition along the height of the combustor, during combustion of MSS at steady state condition. An increase in the temperature is noticed just above the bed, where the fuel is entered into the combustor. The combustion rate at this zone is higher cause of volatile release in this zone whereas the combustion rate in the bed is lower because the bed is operated at the less fuel. In case of air-fired, an increase in temperature is observed in-between $1.4 \mathrm{~m}$ to $1.6 \mathrm{~m}$, where the biomass is burned in the freeboard. Further the temperature falls dramatically at the top of the combustor at $1.8 \mathrm{~m}$. The probable reasons for the same are due to increase in the velocity at that point due to the ID fan etc.
Fig. 2. Combustion temperature along the elevation for dry MSS at $18 \mathrm{~kg} / \mathrm{hr}$ feed rate under steady state.

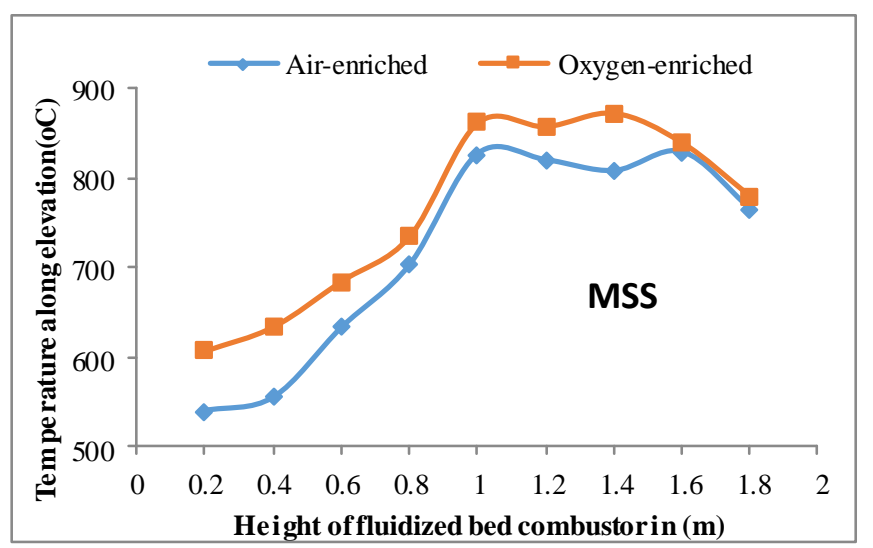

As the oxygen concentration increases (upto $20 \%$ or above) the combustion characteristics change slightly with respect to temperature. Fig. 2 shows that with higher $\mathrm{O}_{2}$ concentration, temperature increases sharply above the bed. It observes that with increase in oxygen concentration the combustion rate is increased, which leads to complete combustion.

\section{B. Flue gas emission}

$\mathrm{NO}_{\mathrm{x}}$ concentration for MSS under steady state, air-fired and oxygen-enriched condition is shown in Fig. 3 at $18 \mathrm{~kg} / \mathrm{hr}$ feed rate. $\mathrm{NO}_{\mathrm{x}}$ production is depending on the nitrogen contents in the fuels and temperature rise. MSS on dray basis has very less nitrogen content produced less $\mathrm{NO}_{\mathrm{x}}$. Result shows that with increase in oxygen concentration, inside the combustor the combustion rate increased which further increases the temperature. $\mathrm{NO}_{\mathrm{x}}$ production is directly proportional to the temperature rise. Fig. 3 shows increased in $\mathrm{NO}_{\mathrm{x}}$ under oxygenenriched condition.

Fig. 3 reports the $\mathrm{CO}$ concentration for MSS under steady state, air-fired and oxygen-enriched condition at $18 \mathrm{~kg} / \mathrm{hr}$ feed rate. It is observed from the figure that the amount of the carbon monoxide decreases with increase in the oxygen concentration. Because at steady state the amount of the fuel is stable and the oxygen content are higher which increase the combustion rate of the fuel. 


\section{Asia Pacific Journals}

Fig. 3. Gas emission measured in freeboard at a feed rate of $18 \mathrm{kh} / \mathrm{hr}$.

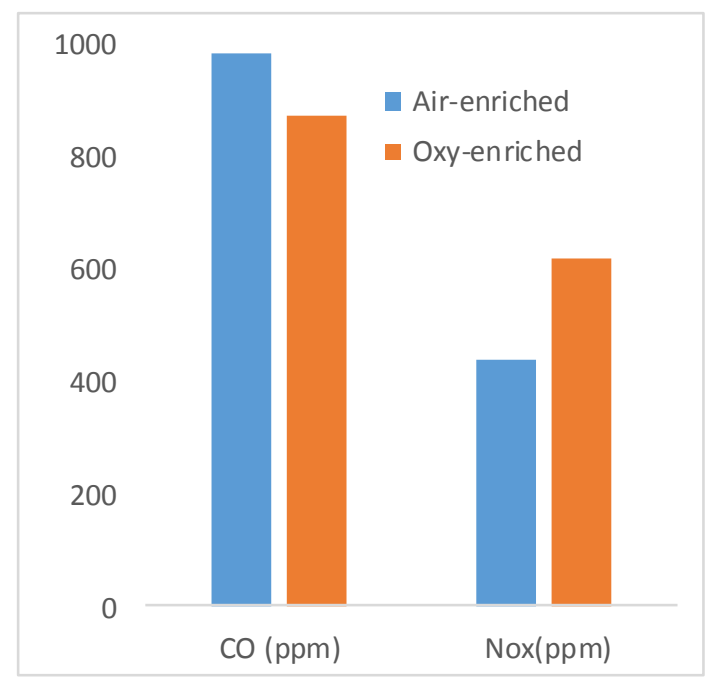

\section{CONCLUSIONS}

An experimental study of the oxygen-enriched bubbling fluidized bed with MSS has been carried out to investigate the combustion temperature and flue gas emission under air-fired and oxygen-enriched condition. It observed that the MSS on dry basis combusted successfully in bubbling fluidized bed under both air-enriched or oxygen-enriched conditions. The burnout inside the combustor is improved with increase of oxygen concentration inside the combustor. When steady state is reached the amount of the fuel supplied is stable. With the increase in combustion rate the concentration of $\mathrm{CO}$ reduces gradually and $\mathrm{NO}_{\mathrm{x}}$ concentration increases.

\section{Acknowledgment}

Authors are thankful to Department of Science and Technology, New Delhi, India for proving financial grant for conducting the research. Author is also thankful to BITS pilani, Pilani Campus, India for their support.

\section{References}

[1] J. Werther and T. Ogada, "Sewage sludge combustion," Progress in Energy and Combustion Science, vol. 25, pp. 55-116, 1999.

[2] N. Gupta, K. K. Yadav, and V. Kumar, "A review on current status of municipal solid waste management in India," Journal of environmental sciences, vol. 37, pp. 206-217, 2015.

[3] R. I. Singh, "Study of fluidized bed combustion power plant using agri residues," Applied Thermal Engineering, vol. 71, no. 1, pp. 616-626, 2014.

[4] X. Han, M. Niu, X. Jiang, and J. Liu, "Combustion Characteristics of Sewage Sludge in a Fluidized Bed," Industrial \& engineering chemistery research, vol. 51, pp. 10565-10570, 2012.

[5] J. Zhu, Y. Yao, Q. Lu, M. Gao, and Z. Ouyang, "Experimental investigation of gasification and incineration characteristics of dried sewage sludge in a circulating fluidized bed," FUEL, vol. 150, no. x, pp. 441-447, 2015

[6] H. Jang, J. Kim, S. Back, J. Sung, H. Yoo, H. Seok, and Y. Seo, "Combustion characteristics of waste sludge at air and oxy-fuel combustion conditions in a circulating fluidized bed reactor," FUEL, vol. 170, pp. 92-99, 2016. 